\title{
Disinfectant Efficacy Against Dry Surface Biofilms of Staphylococcus Aureus and Pseudomonas Aeruginosa Is Product, Time Point and Strain Dependent
}

\author{
Carine A Nkemngong \\ Purdue University \\ Gurpreet K Chaggar \\ Purdue University \\ Xiaobao Li \\ Diversey, Inc \\ Peter J Teska \\ Diversey, Inc \\ Haley F Oliver ( $\square$ hfoliver@purdue.edu ) \\ Purdue University https://orcid.org/0000-0002-5851-6523
}

\section{Research}

Keywords: Dry surface biofilms, disinfectants, Staphylococcus aureus, Pseudomonas aeruginosa

Posted Date: March 26th, 2021

DOI: https://doi.org/10.21203/rs.3.rs-315705/v1

License: (a) This work is licensed under a Creative Commons Attribution 4.0 International License. Read Full License 


\section{Abstract}

\section{Background:}

Globally, healthcare associated infections (HAl) are the most frequent adverse outcome in healthcare delivery. Although bacterial biofilms contribute significantly to the incidence of HAl, few studies have investigated the efficacy of common disinfectants against dry surface biofilms (DSB). The objective of this study was to evaluate the bactericidal efficacy of seven disinfectants against DSB of Staphylococcus aureus and Pseudomonas aeruginosa. We hypothesized that overall, hydrogen peroxides, sodium dichloro-s-triazinetrione and quaternary ammonium compounds plus alcohol disinfectants will be more bactericidal against DSB than quaternary ammonium. We also hypothesized that regardless of differences in product chemistries, higher bactericidal efficacies against DSB will be exhibited after $24 \mathrm{~h}$ of dehydration compared to $72 \mathrm{~h}$.

Methods: Wet surface biofilms of $S$. aureus and $P$. aeruginosa were grown following EPA-MLB-SOP-MB-19 and dehydrated for $24 \mathrm{~h}$ and $72 \mathrm{~h}$ to establish DSB. Seven EPA-registered disinfectants were tested against dehydrated DSB following EPA-MLB-SOP-MB-20.

Results: Overall, quaternary ammonium plus alcohol, sodium dichloro-s-triazinetrione, and hydrogen peroxide products were more efficacious against DSB than quaternary ammoniums for both tested strains. While there was no significant difference in biofilm killing efficacies between $24 \mathrm{~h}$ and $72 \mathrm{~h} \mathrm{~S}$. aureus biofilms, significantly higher $\log _{10}$ reductions were observed when products were challenged with $24 \mathrm{~h} P$. aeruginosa DSB compared to $72 \mathrm{~h} P$. aeruginosa DSB.

Conclusion: Strain type, active ingredient class, and dry time significantly impact disinfectant efficacy against DSB of $S$. aureus or $P$. aeruginosa.

\section{Background}

Healthcare associated infections (HAl), a result of diverse interactions among modern healthcare practices, hospital environments, and growing antibiotic resistance, among other factors, pose a crucial threat to human well-being [1]. Globally, the acquisition of HAl is the most frequent adverse outcome in healthcare delivery [2]. In the United States, approximately 633,300 patients are affected by $687,200 \mathrm{HAI}[3]$ with more than 72,000 deaths every year [4]. In Europe, about 4.5 million HAl occur yearly in acute care hospitals [5] with about approximately 135,000 deaths [6]. In low and middle income countries (LMIC), the density of HAl in adult intensive care units is estimated at 47.9 per 1,000 patient days, which is higher than rates in the US and Europe [7]. Comparing HAl incidence rates in developed and LIMC, the incidence rate is seven out of 100 patients in developed economies and ten out of a 100 in LMIC [8].

The prevalence of HAl has been associated with biofilm formation by bacteria [9]. Bacterial biofilms are ubiquitous and represent approximately $99 \%$ of the world's known bacterial population [10]. The National Institutes of Health (NIH) of the US estimates that about $80 \%$ of all chronic infections are due to biofilm formation [9]. Biofilms are comprised of microbial cells adhered to a surface and to each other, forming a microcolony encased in a polysaccharide dominant matrix [11]. In addition to the cells that inhabit a biofilm, DNA, proteins and biosurfactants are prevalent [12]. Bacterial biofilms are persistent on environmental surfaces due to the ability to adhere to common surfaces and the extracellular polymeric substances (EPS) they produce [13]. The EPS forms a matrix that presents a major barrier to removal from surfaces in healthcare facilities as it is "resistant" to physical stress [14] and shields underlying bacterial cells from direct contact with disinfectants [15]. As a result of the EPS matrix [11Donlan, 2000], the presence of efflux pumps and persister cells [16], bacterial biofilms are about 1,000 times less susceptible to disinfectants than their planktonic counterparts [17]. Additionally, the ability for disinfectants to penetrate the biofilm matrix is affected by the water binding characteristic of the EPS matrix [11], and pH differences among various layers of biofilms [18]. These features may result in the aggregation of organic acids leading to the deactivation of less potent disinfectants that may be non-lethal [18].

Bacterial biofilms have the ability to develop and persist for up to 12 months [19] on wet and dry surfaces in the hospital environment despite repeated cleaning [20]. Dry surface biofilms (DSB) are particularly widespread on surfaces in healthcare facilities [20, 21]. In a recent 2018 study by Ledwoch et al., DSB were detected in $95 \%$ of 61 samples collected from hospitals in Wales [22]. Such surfaces included commodes, clipboards and sanitizing bottles [22]. DSB have also been detected on indwelling catheters [23]. Although multi-species dry surface biofilms have been detected on a range of surfaces in healthcare facilities, major HAl pathogens as $S$. aureus [22] and $P$. aeruginosa are predominant $[24,25]$.

While DSB are widespread on surfaces in healthcare facilities, they are also harder to kill than wet surface biofilms [26]. This is the case as overall, DSB are characterized by a denser EPS matrix than wet surface biofilms [26, 27]. Moreover, with prolonged desiccation and starvation of bacteria in DSB, there is an increase in the overall percentage of protein content and slightly decreased carbohydrate content compared to wet surface biofilms $[26,28]$ Being the principal component of biofilms, this increase in the proportion of proteins may further contribute towards the reduced bactericidal efficacy of disinfectants against DSB. [29]. Biofilms may survive longer due to metabolic changes that may result from cell-cell signaling and from the presence of a biofilm matrix that facilitates nutrient recycling and transformation from lysed cells [30]. 
In the current protocol used by the Environmental Protection Agency (EPA) for biofilm claims on disinfectants, wet surface biofilms of $S$. aureus and $P$. aeruginosa are the required test pathogens [31]. Under real world conditions such as in healthcare facilities, disinfectants are relied on to inactivate bacteria on dry surfaces [32], which are usually in the form of DSB [26]. Despite widespread evidence that bacteria in healthcare environments are more likely to be encased in DSB, the standard test for disinfectant efficacy testing and registration with the EPA are conducted using planktonic bacteria or bacteria in wet biofilms. To the best of our findings, no studies have evaluated the bactericidal efficacy of disinfectants against dry surface biofilms of $S$. aureus and $P$. aeruginosa established at different dehydration time points consistent with routine cleaning and disinfection schedules recommended by the CDC [33]. In a previous study, our group developed a rapid model for establishing DSB of $S$ aureus and $P$. aeruginosa at different time points and at mean $\log _{10}$ densities sufficient for disinfectant efficacy testing [34]. In this study, we evaluated the bactericidal efficacy of seven liquid disinfectants against DSB of $S$. aureus and $P$. aeruginosa after $24 \mathrm{~h}$ and $72 \mathrm{~h}$ of dehydration. We hypothesized that overall, hydrogen peroxide, sodium dichloro-s-triazinetrione, and quaternary ammonium compounds plus alcohol disinfectants will be more bactericidal against DSB than quaternary ammonium disinfectants based on our prior work. We also hypothesized that regardless of differences in product chemistries, higher bactericidal efficacies against DSB will be exhibited after 24 h of biofilm dehydration compared to $72 \mathrm{~h}$ of dehydration.

\section{Methods}

\section{Bacteria strains and disinfectants tested in this study}

DSB of S. aureus ATTC-6538 and P. aeruginosa ATCC-15442 were established on borosilicate glass coupons (1.27 $\pm 0.013 \mathrm{~cm}$; Biosurface Tech, Inc.) following Nkemngong et al., 2020 [34]. These strains were selected as they are standard strains of choice for disinfectant efficacy testing

[31]. They are also the standard EPA strains for registering disinfectants with claims against wet surface bacterial biofilms [35].

Table 1 Active ingredients and contact times for disinfectants tested in this study.

\begin{tabular}{|c|c|c|c|c|}
\hline $\begin{array}{l}\text { Disinfectant } \\
\text { product }^{\mathrm{a}}\end{array}$ & Disinfectant Active Ingredient(s) ${ }^{d}$ & $\begin{array}{l}\text { Dilution } \\
\text { at use }\end{array}$ & $\begin{array}{l}\text { Active level at } \\
\text { use }^{\mathrm{e}}\end{array}$ & $\begin{array}{l}\text { Label contact time } \\
\text { (mins) }^{f}\end{array}$ \\
\hline $\mathrm{CL}^{\mathrm{b}}$ & $48.21 \%$ sodium dichloro-s-triazinetrione & RTUd & 4,306 ppm & 4 \\
\hline $\mathrm{SH}$ & $0.39 \%$ sodium hypochlorite & RTU & $0.39 \%$ & 1 \\
\hline HP1 & $0.5 \%$ hydrogen peroxide & RTU & $1.4 \%$ & 1 \\
\hline HP2 & $0.5 \%$ hydrogen peroxide & RTU & $0.5 \%$ & 1 \\
\hline $\mathrm{QA} 1^{\mathrm{C}}$ & $\begin{array}{l}0.25 \% \text { n-alkyl }\left(68 \% \mathrm{C}_{12}, 32 \% \mathrm{C}_{14}\right) \text { dimethyl ethylbenzyl } \\
\text { ammonium chloride } \\
0.25 \% \text { n-alkyl }\left(60 \% \mathrm{C}_{14}, 30 \% \mathrm{C}_{16}, 5 \%\right. \\
\left.\mathrm{C}_{12}, 5 \% \mathrm{C}_{18}\right) \text { dimethyl benzyl ammonium chloride } \\
55 \% \text { isopropanol }\end{array}$ & RTU & $0.5 \% g+55 \%$ & 2 \\
\hline QA2 & $\begin{array}{l}0.76 \% \text { didecyldimethyl ammonium chloride } \\
15 \% \text { isopropanol } \\
7.50 \% \text { ethanol }\end{array}$ & RTU & $\begin{array}{l}0.76 \%^{g}+ \\
22.5 \%\end{array}$ & 1 \\
\hline$Q T^{c}$ & $\begin{array}{l}0.14 \% \text { n-alkyl }\left(68 \% \mathrm{C}_{12}, 32 \% \mathrm{C}_{14}\right) \text { dimethyl ethylbenzyl } \\
\text { ammonium chloride } \\
0.14 \% \text { n-alkyl }\left(60 \% \mathrm{C}_{14}, 30 \% \mathrm{C}_{16}, 5 \%\right. \\
\left.\mathrm{C}_{12}, 5 \% \mathrm{C}_{18}\right) \text { dimethyl benzyl ammonium chloride }\end{array}$ & RTU & $0.28 \%$ & 3 \\
\hline
\end{tabular}

a Abbreviated naming scheme for commercially available EPA registered disinfectants used in this study;

b Tablet, ready-to-use (RTU) concentration prepared following manufacturer guidelines;

${ }^{\mathrm{c}}$ Liquid expensed from RTU disinfectant wipes;

d RTU concentration; 
${ }^{\mathrm{e}}$ Active ingredient concentration after dilution;

${ }^{f}$ Defined label contact time;

g Total quaternary ammonium plus alcohol content.

\section{DSB establishment on borosilicate glass coupons}

DSB of S. aureus ATTC-6538 and P. aeruginosa ATCC-15442 were established on borosilicate glass coupons ( $1.27 \pm 0.01 \mathrm{~cm}$; Biosurface Tech, Inc., Bozeman, MT) following Nkemngong et al., 2020 [34]. Wet surface biofilms were established following EPA-MLB-SOP-MB-19 through batch and continuous stir tank reactor (CSTR) phases [35]. The batch medium was $3.0 \mathrm{~g} / \mathrm{L}$ TSB for S. aureus and $300 \mathrm{mg} / \mathrm{L}$ TSB for $P$. aeruginosa. A $500 \mathrm{ml}$ batch medium held in a CDC biofilm reactor (Biosurfaces Technologies, Inc., Bozeman, MT) was inoculated with one ml of an overnight culture of $S$. aureus or $P$. aeruginosa. The batch phase lasted $24 \pm 2 \mathrm{~h}$ with the CDC biofilm reactor (Biosurfaces Technologies, Inc., Bozeman, MT) mounted on a magnetic hot plate stirrer (Talbays, Thorofare, NJ) set at $60 \pm 5 \mathrm{rpm}$ at $36 \pm 1^{\circ} \mathrm{C}$ for $S$. aureus or $125 \pm 5 \mathrm{rpm}$ at $21 \pm 2^{\circ} \mathrm{C}$ for $P$. aeruginosa. CSTR medium in $20 \mathrm{~L}$ of sterile distilled water had a final concentration of $1.0 \mathrm{~g} / \mathrm{L}$ TSB for $S$. aureus and $100 \mathrm{mg} / \mathrm{L} \mathrm{TSB}$ for $P$. aeruginosa. CSTR medium was continuously pumped through the CDC biofilm reactor for $24 \pm 2 \mathrm{~h}$ for both strains.

After wet surface biofilms were established through the batch and CSTR phases, rods from the CDC biofilm reactor; each holding three borosilicate glass coupons were dehydrated for $24 \mathrm{~h}$ and $72 \mathrm{~h}$ at $25^{\circ} \mathrm{C}$ or $21^{\circ} \mathrm{C}$ for $S$. aureus and $P$. aeruginosa, respectively. Dry times and dehydration temperatures were informed by Nkemngong et al., 2020 [34].

\section{Disinfectant efficacy testing against DSB of $S$. aureus and $P$. aeruginosa}

At each dehydration time point (24 h and $72 \mathrm{~h}$ ), disinfectants (Table 1) were tested against DSB following EPA-MLB-SOP-MB-20 [35]. At each dry time and for each disinfectant product, three coupons with DSB of $S$. aureus or $P$. aeruginosa were harvested into sterile 50 ml conical tubes. Three coupons each after $24 \mathrm{~h}$ and $72 \mathrm{~h}$ of dehydration served as negative controls; controls were treated with four ml of phosphate buffer saline (PBS) with a one-minute contact time. At each of the dry times, three harvested coupons (technical replicates) were independently treated with four $\mathrm{ml}$ of each disinfectant (Table 1). At the label-defined contact time of each disinfectant product and PBS, $36 \mathrm{ml}$ of neutralizing buffer ( $1 \mathrm{~L} \mathrm{H}_{2} \mathrm{O}+5.2 \mathrm{~g}$ Difco neutralizing buffer; Becton, Dickinson and Company Sparks, MD) was added to each treated coupon to stop the disinfectant action. Treated coupons were vortexed and sonicated to release DSB from coupons into solution as described by Nkemngong et al., 2020 [34]. Post treatment with disinfectants, DSB of $S$. aureus or P. aeruginosa were vacuum-filtered onto filter membranes following EPA-MLBSOP-MB-20 [35]. Negative controls were spread plated following EPA-MLB-SOP-MB-20 [35]. Eight biological replicates were completed for QA and QT products and five biological replicates for CL, SH and HP products as informed by Lineback et al., 2018 [36].

\section{Statistical analysis}

$\log _{10}$ reductions resulting from the treatment of coupons with DSB were calculated and used for statistical analyses. Specifically, mean bacterial $\log _{10}$ densities per coupon were calculated for disinfectant and PBS-treated coupons. Mean $\log _{10}$ densities per disinfectant-treated coupon were normalized against the mean $\log _{10}$ densities of control coupons to determine $\log _{10}$ reductions. The least squares method of the PROC GLIMMIX procedure was used to analyze and compare mean $\log _{10}$ reductions ( $n=70$ per strain; $\left.N=140 ; a=0.05\right)$ among the seven tested disinfectant products. The same test was used to statistically compare mean $\log _{10}$ reductions at $24 \mathrm{~h}$ and $72 \mathrm{~h}$. Pair-wise comparisons among products, strains, and dry times were completed with Tukey adjustments. All statistical procedures were completed using SAS version 9.4 (SAS Institute, Cary, NC).

\section{Results}

\section{Dry time does not significantly impact disinfectant efficacy against $S$. aureus DSB, unlike $P$. aeruginosa DSB}

Mean $\log _{10}$ densities of $S$. aureus DSB per control coupon after $24 \mathrm{~h}$ and $72 \mathrm{~h}$ of dehydration were $7.64 \pm 0.76$ and $7.00 \pm 0.89$, respectively. On average, the bactericidal efficacies for all tested disinfectants against $S$. aureus DSB at $24 \mathrm{~h}$ and $72 \mathrm{~h}$ dehydration time points were $6.30 \pm 1.27$ and $5.89 \pm 1.21$, respectively. There was no significant difference between the average $\log _{10}$ reductions per coupon of $S$. aureus DSB at $24 \mathrm{~h}$ compared to $72 \mathrm{~h}(\mathrm{P}>0.05$; Figure 1).

The average $\log _{10}$ densities of $P$. aeruginosa DSB per coupon pre-treatment were $7.40 \pm 0.75$ and $6.77 \pm 0.61$ after $24 \mathrm{~h}$ and $72 \mathrm{~h}$ dry times, respectively. There were no significant differences between the average $\log _{10}$ density per coupon after $24 \mathrm{~h}$ and $72 \mathrm{~h}$ of dehydration (P凶0.005). On average, the mean $\log _{10}$ reduction per coupon for all tested disinfectants after $24 \mathrm{~h}$ and $72 \mathrm{~h}$ were $5.50 \pm 1.45$ and $4.65 \pm 1.63$, respectively. 
Overall and regardless of the product type or active ingredient class, significantly higher bactericidal efficacies against DSB of $P$. aeruginosa were recorded after $24 \mathrm{~h}$ compared to $72 \mathrm{~h}$ of dehydration $(\mathrm{P}<0.05$; Figure 1$)$.

\section{Bactericidal efficacy against $S$. aureus DSB varies by product type and active ingredient class}

The average $\log _{10}$ densities of $S$. aureus DSB per coupon pre-treatment after $24 \mathrm{~h}$ and $72 \mathrm{~h}$ dry times were $7.64 \pm 0.76$ and $7.0 \pm 0.89$, respectively. Overall, there were significant differences among the product types and active ingredient classes ( $P<0.05$; Figure 2$)$. Irrespective of the dry time $(24 \mathrm{~h}$ or $72 \mathrm{~h}), \log _{10}$ reduction for QA2 (6.11 \pm 1.30$), \mathrm{HP} 2(6.18 \pm 1.72), \mathrm{HP} 1(6.34 \pm 1.154), \mathrm{SH}(6.45 \pm 0.87), \mathrm{CL}(6.57 \pm 1.11)$, and QA1 (6.61 \pm 0.80$)$ resulted in significantly higher $\log _{10}$ reductions than QT $(6.12 \pm 1.30)(P<0.05$; Figure 2$)$. However, there were no statistically relevant differences among the mean $\log _{10}$ reductions per coupon for QA1, QA2, CL, SH, HP1 and HP2 (P>0.05; Figure 2).

Overall, the mean $\log _{10}$ reduction per coupon per product type were QT (4.85 \pm 0.86$)$, HP (6.19 \pm 1.43$), \mathrm{QA}(6.36 \pm 1.10)$, SH (6.45 \pm 0.87$)$, and $\mathrm{CL}(6.57 \pm 1.11)$ (Figure 3). QA, CL, SH and HP products were more bactericidal than the QT product $(\mathrm{P}<0.05$; Figure 3$)$. However, there were no statistically significant differences in the bactericidal efficacies between QA and HP; CL and SH, SH and QA, CL and HP, SH and HP, and CL and QA when disinfectants were challenged with $S$. aureus DSB ( $>0.05$; Figure 3).

\section{Mean $\log _{10}$ reductions for $P$. aeruginosa DSB were higher for oxidizing agents compared to quaternary ammonium products}

The mean $\log _{10}$ density of $P$. aeruginosa DSB per coupon was $7.08 \pm 0.75$ after dehydration $(24 \mathrm{~h}$ and $72 \mathrm{~h})$ and pre-treatment. Overall, product type and active ingredient class were significant $(\mathrm{P}<0.0001$; Figure 2$)$. Regardless of the dry time $(24 \mathrm{~h}$ or $72 \mathrm{~h})$, there were significantly higher $\log _{10}$ reductions for HP1 (5.97 \pm 1.23$)$ and HP2 (6.30 \pm 1.26$)$ as compared to QA1 (4.20 \pm 0.71$)$, QT (3.82 \pm 0.53$)$, and SH (3.23 \pm 1.53$)$ (P<0.05; Figure 2). Similarly, CL $(5.79 \pm 1.40)$ and QA2 $(5.85 \pm 0.87)$ had significantly higher $\log _{10}$ reductions against $P$. aeruginosa DSB than QA1, QT and $\mathrm{SH}(\mathrm{P}<0.05$; Figure 2). However, there were no statistically significant differences among QA1, QT and SH (Pख0.05; Figure 2). There were also no statistically significant differences in the bactericidal efficacies of HP1, HP2, CL and QA2 (Pख0.05; Figure 2).

There were statistically significant differences among active ingredient classes (CL, HP, SH, QA and QT (P<0.0001; Figure 3). Overall, HP products resulted in a significantly higher bactericidal efficacy than QT and SH products $(\mathrm{P}<0.05$; Figure 3$)$. Similarly, $\mathrm{CL}$ and $\mathrm{QA}$ products had significantly higher mean $\log _{10}$ reductions than QT and SH products $(\mathrm{P}<0.05$; Figure 3$)$. However, there were no differences between QT and $\mathrm{SH}$, CL and HP, HP and QA, and QA and SH products (P凶0.05; Figure 3).

\section{Higher bactericidal efficacy against $S$. aureus DSB than $P$. aeruginosa DSB}

Overall, and regardless of the product type, the bacterial strain was statistically significant $(\mathrm{P} P<0.05)$. The overall mean log 10 reductions for $S$. aureus and $P$. aeruginosa were $6.096 \pm 1.251$ and $4.941 \pm 1.505$ respectively. Significantly higher $\log _{10}$ reductions were observed when the tested disinfectants were challenged with $S$. aureus compared to $P$. aeruginosa $(P<0.05)$.

\section{Discussion}

In this study, we employed a rapid DSB model previously developed by our group for disinfectant efficacy testing and evaluated the bactericidal efficacy of seven EPA-registered disinfectants against $24 \mathrm{~h}$ and $72 \mathrm{~h}$ old DSB of $S$. aureus and $P$. aeruginosa. Specifically, we established DSB of $S$. aureus and $P$. aeruginosa at $25^{\circ} \mathrm{C}$ and $21^{\circ} \mathrm{C}$ respectively to mimic environmental conditions for the formation of DSB on dry contaminated hard non-porous surfaces in healthcare facilities.

We found that mean $\log _{10}$ densities per coupon from this study were comparable to the ranges previously reported by Nkemngong et al., 2020 [34]. We found that overall and irrespective of dry time, CL, SH, HP and QA disinfectants were significantly more bactericidal against DSB of $S$. aureus than QT disinfectants. We also found that when DSB of $P$. aeruginosa were challenged with disinfectants, CL and HP were significantly more bactericidal than SH and QT disinfectants. Overall, we demonstrated that prolonged dehydration had varied effects on the bactericidal efficacy of disinfectants against DSB of $S$. aureus or $P$. aeruginosa. Specifically, we found that there were no significant differences in the bactericidal efficacies of disinfectants against $24 \mathrm{~h}$ and $72 \mathrm{~h}$ DSB of $S$. aureus. There was however, a significantly lower log 10 reduction against $72 \mathrm{~h}$ DSB of $P$. aeruginosa compared to $24 \mathrm{~h}$ DSB of the same strain.

\section{Bactericidal efficacy varies by strain after prolonged dehydration}

Our study found differences in the overall bactericidal efficacy of disinfectants against DSB of $S$. aureus and $P$. aeruginosa after prolonged dehydration for $24 \mathrm{~h}$ and $72 \mathrm{~h}$. While there was no significant difference in $\log _{10}$ reductions between $24 \mathrm{~h}$ and $72 \mathrm{~h}$ DSB of $S$. aureus, the reverse was true for DSB of $P$. aeruginosa as $72 \mathrm{~h}$ DSB of $P$. aeruginosa were harder to kill than their $24 \mathrm{~h}$ counterparts. In a previous study by our group, we found that $100 \%$ of $P$. aeruginosa DSB established at a dehydration temperature of $21^{\circ} \mathrm{C}$ were encased in EPS while this was true for only 
$92 \%$ of $S$. aureus DSB established at $25^{\circ} \mathrm{C}$ [34]. The consistent presence of EPS on DSB of $P$. aeruginosa at dehydration time points from $24 \mathrm{~h}$ to $120 \mathrm{~h}$ as previously demonstrated by our group suggested that older DSB of $P$. aeruginosa developed using our model may be encased in more EPS; making them harder to kill [34]. This is consistent with previous studies that have demonstrated the presence of a thick EPS matrix as a major factor for reduced bactericidal efficacy in biofilms compared to planktonic bacteria [29]. Moreover, previous studies [26, 37] have also suggested that unfavorable conditions such as dehydration may trigger bacterial biofilms to produce more EPS. While this may be true for $P$. aeruginosa DSB as evidenced in our previous study, the same may not be the case for $S$. aureus DSB as we found that older $S$. aureus DSB (72 h) were overall encased in less EPS matrix than $24 \mathrm{~h}$ biofilms [34]. More EPS production translates into a thicker barrier for disinfectants to bypass before contact with underlying bacteria. Additionally, a thicker EPS matrix may also result in a range of $\mathrm{pH}$, which can impact bactericidal efficacy [18]. These factors could account for the reduced bactericidal efficacy against $72 \mathrm{~h}$ DSB of $P$. aeruginosa compared to $72 \mathrm{~h}$ DSB of $S$. aureus.

\section{Product type and class significantly impact disinfectant efficacy against $S$. aureus DSB}

There were significant differences among products, with QA1, QA2, CL, SH and HP1 being more bactericidal than QT. In a related study against $S$. aureus wet surface biofilms, Lineback et al., demonstrated that one sodium hypochlorite and five hydrogen peroxide disinfectants were significantly more bactericidal than two quaternary ammonium compounds [36]. This could be explained by the production of reactive oxygen species (ROS) by hydrogen peroxide disinfectants. The production of ROS results in more necrotic death compared to quaternary ammonium compounds as ROS result in DNA damage [38]. Comparatively, quaternary ammonium compounds mainly rely on a positively charged N-atom to bind to cell membranes, creating "pores" for n-alkyl side chains to transverse the cell membrane resulting in lysis and leakage of cytoplasmic contents $[39,40]$. Considering the denser EPS produced by DSB compared to wet surface biofilms, this may present a significant barrier for quaternary ammonium products compared to sodium dichloro-s-triazinetrione, sodium hypochlorite and hydrogen peroxides. Moreover, oxidizing agents such as sodium dichloro-s-triazinetrione, sodium hypochlorite and hydrogen peroxides have low molecular weight active ingredients that when compared to larger molecules such as quaternary ammonium, can more easily bypass the cell membrane to damage internal cellular components [38]. This could further explain the observation that sodium dichloro-s-triazinetrione, sodium hypochlorite and hydrogen peroxide products were overall more bactericidal against DSB of $S$. aureus than quaternary ammonium. Quaternary alcohol products may have resulted in significantly higher bactericidal efficacies owing to the "rapid" bactericidal mode of action of alcohol [41].

We also found that the mean $\log _{10}$ reductions between HP1 and HP2; QA1 and QA2 were comparable when disinfectants were challenged with S. aureus DSB This finding is consistent with the findings of Lineback et al., 2018 who reported no significant differences among the bactericidal efficacies of five hydrogen peroxide products tested against $S$. aureus wet surface biofilms [36]. Similarly, in a recent study that evaluated the bactericidal efficacies of six disinfectant wipes against $S$. aureus ATTC-6538 inoculated on hard-non-porous surfaces, Voorn et al., reported no significant differences in the bactericidal efficacies among three hydrogen peroxide products or three quaternary alcohol products [42]. However, we found that quaternary alcohol products were overall more bactericidal than quaternary ammonium products without alcohol. This suggest that the defined percentage of alcohol added to quaternary ammonium compounds influences bactericidal efficacy; alcohol confers a rapid and more potent (tuberculocidal) action against bacteria [41].

\section{$\mathrm{HP}$ and $\mathrm{CL}$ products are more bactericidal against $P$. aeruginosa DSB than SH, QT and QA products}

Overall, CL, QA2, HP1 and HP2 had significantly higher $\log _{10}$ reductions against $P$. aeruginosa DSB than QA1, QT and SH. Our findings are similar to those of West et al., who demonstrated that hydrogen peroxide-based disinfectants are overall, more bactericidal against $P$. aeruginosa allowed to dry on a Formica disc than quaternary ammonium disinfectants [43]. In another study, Tote et al. found that hydrogen peroxides had a stronger antibiofilm activity against one day old $P$. aeruginosa biofilms as they were biologically active against both viable $P$. aeruginosa cells and their EPS matrix unlike isopropanol disinfectants [44]. The high efficacy of HP1 and HP2 compared to SH against DSB could be explained by the relatively low concentration (0.39\%) of sodium hypochlorite in SH as in a 2018 study, Lineback et al. compared the bactericidal efficacies of $0.5 \%$ hydrogen peroxide and $1.312 \%$ sodium hypochlorite disinfectants against wet surface biofilms of $P$. aeruginosa, and found no difference in their efficacies [36]. The same intrinsic factor of a relatively low sodium hypochlorite concentration in SH may also account for the higher bactericidal efficacy of $\mathrm{CL}$ compared to $\mathrm{SH}$ as in a study by Tiwari et al., $0.60 \%$ sodium hypochlorite resulted in superior bactericidal efficacy against clinical isolates of $S$. aureus biofilms [45]. These reports suggest that although sodium hypochlorite is generally more bactericidal than quaternary ammoniums owing to their mode of action, the degree of disinfection is largely concentration dependent.

Although QA2 had a higher quaternary ammonium and lower alcohol content $(0.76 \%$ quat $+22.5 \%$ alcohol) than QA1 (0.5\% quat $+55 \%$ alcohol) (Table 1), QA2 demonstrated a significantly higher kill against $P$. aeruginosa DSB than QA1. This suggests that the synergistic effect of quaternary ammonium compounds and alcohol in QA1 may not be sufficient. Moreover, in a 2018 study by Wesgate et al., the authors reported that quaternary ammonium formulations with side alkyl chains in the $\mathrm{C}_{12-16}$ range as is the case for QA1 were more adsorbed to different wipe material types than other formulations [46]. Consequently, and considering that wipes were "wringed" to dispense disinfectant liquid from QA1, 
the quaternary ammonium compound in QA1 may have been more adsorbed to the wipe material than QA1, resulting in a lower final disinfectant liquid concentration in QA1 than QA2 [46].

\section{$P$. aeruginosa DSB are harder to inactivate than $S$. aureus DSB}

Our data delineate statistically significant higher average $\log _{10}$ reductions when disinfectants were treated against $S$. aureus DSB compared to $P$. aeruginosa DSB. Overall, the low bactericidal efficacy of disinfectants against biofilms is often linked to the EPS matrix [47]. The reduced efficacy of disinfectants, regardless of the product type, observed with Gram-negative $P$. aeruginosa can be partially explained by the presence of alginate, Psl, Pel [48], and extracellular DNA (eDNA) [49] as important components of the biofilm matrix characteristic of $P$. aeruginosa. Specifically, the overproduction of alginates by $P$. aeruginosa mutants result in the formation of larger microcolonies than wildtype strains [50]. This suggests a role for alginates in decreased susceptibility to antimicrobials [51] compared to non-alginate-producing bacteria such as $S$. aureus [48]. Pel, on the other hand, plays a vital role in cell-to-cell interactions within these biofilms [52] and in the biofilm maturation [49]. A spike in alginate and carbohydrate production during biofilm formation and maturation confers an overall increase in the net negative charge of the EPS matrix, enhancing the electrostatic attractions between the EPS matrix and positively charged antimicrobials as quaternary ammonium compounds [47]. This limits the diffusion of cationic antimicrobials through the EPS matrix, thus shielding the underlying bacteria from direct antimicrobial contact [47]. However, the cell wall of Gram-positive bacteria such as $S$. aureus is essentially composed of peptidoglycan and teichoic acid and substances with high molecular weight can traverse the cell wall. [53]. This may explain the higher log ${ }_{10}$ reductions observed against $S$. aureus DSB compared to $P$. aeruginosa DSB exposed to quaternary alcohol and quaternary ammonium products.

Our results suggest that comparatively higher mean $\log _{10}$ reductions are achieved when sodium hypochlorite was challenged with $S$. aureus compared to $P$. aeruginosa DSB. This could be due to the act that negatively charged disinfectants as sodium hypochlorite destroy the cellular activity of bacterial proteins [54] and are capable of increased penetration of outer cell layers even in unionized state [53]. Similarly, hydroxyl free radicals from HP based products specifically target sulfhydryl groups, double bonds [55] and destroy bacterial lipids, proteins, and DNA. Our data is in accordance with Lineback et al., 2018 who suggested that sodium hypochlorite products are overall, more effective against $P$. aeruginosa and $S$. aureus WSB compared to quaternary ammonium products [36].

Our results support previous findings that DSB are harder to kill than planktonic bacteria; all the products tested in this study are EPA registered, indicating high levels of efficacy against planktonic bacteria of $S$. aureus and $P$. aeruginosa. To reduce patient safety risks in healthcare facilities, it is critical to conduct baseline disinfectant efficacy testing for product registration using bacteria biofilms representing healthcare environments.

We acknowledge that the scope of our study is limited as we did not investigate the bactericidal efficacy of the tested products against mixed culture bacterial biofilms common on dry contaminated hard-non-porous surfaces in healthcare facilities. We also acknowledge that our study did not specifically investigate disinfectant efficacy against DSB of $S$. aureus and $P$. aeruginosa subjected to longer hours of dehydration as this could impact the efficacy levels of commonly used disinfectants. A wider range of disinfectant active ingredients could have also been investigated. However, this study has set the foundation for future investigations of DSB of $S$. aureus and $P$. aeruginosa.

\section{Conclusion}

Although it is generally agreed that DSB pose a severe challenge for the disinfection of hard non-porous surfaces in healthcare facilities and are a significant contributor to the incidence of HAl, the success of any disinfection regime is dependent on multiple intrinsic and extrinsic factors. Our study definitively demonstrated that significant kill levels of the DSB of major healthcare pathogens that cause HAI can be achieved although this is highly dependent on the choice of disinfectant, active ingredient class, DSB "age" and bacteria strain. It is therefore critical for healthcare stakeholders to consider these factors in efforts to reduce HAl rates.

\section{Abbreviations}

ATCC: American type Culture collection

CDC: Center for Disease Control

DSB: Dry surface biofilms

EPA: Environmental Protection Agency

EPS: Extracellular polymeric substances

HAl: Healthcare-associated infection 
PBS: Phosphate buffered saline

WSB: Wet surface biofilms

\section{Declarations}

Ethics approval and consent to participate: Not applicable

Consent for publication: Not applicable

Availability of data and material: All quantitative data generated or analysed during this study are included in this published article.

Competing interests: HFO, CAN, GKC, report grants from Diversey, Inc. during this study. PT and XL report grants from Diversey, Inc. during this study. There were no personal fees from Diversey, Inc..

Funding: This work was supported by Diversey Inc., Fort Mill, SC, USA.

Authors' contributions: CAN and GKC conducted the wet lab procedures, analysed and interpreted the data generated, and wrote the manuscript. $\mathrm{XL}$ provided industry experience, designed elements of the experimental protocol, and was a contributor in writing and editing the manuscript. PT also provided industry experience and was a contributor in writing and editing the manuscript. HFO served as the principal investigator for the study and was a contributor in writing and editing the manuscript. All authors read and approved the final manuscript.

Acknowledgements: Dr. Oliver is supported by the USDA National Institute of Food and Agriculture Hatch project 2016-67017-24459.

\section{References}

1. Al-Tawfiq JA, Tambyah PA. Healthcare associated infections (HAI) perspectives. J Infect Pub Health. 2014;7:339-34.

2. World Health Organization. Infection prevention and control; the burden of healthcare-associated infection worldwide. WHO. 2021. https://www.who.int/infection-prevention/publications/burden_hcai/en/. Accessed 15 February 2021.

3. Magill SS, Edwards JR, Bamberg W, Beldavs ZG, Dumyati G, Kainer MA, Lynfield R, Maloney M, McAllister-Hollod L, Nadle J, Ray SM, Thompson DL, Wilson LE, Fridkin SK. Multistate point-prevalence survey of health care-associated infections. N Engl J Med. 2014;370:1198-208.

4. Center for Disease Control and Prevention. Overview: healthcare-associated infections. CDC. 2020. https://www.cdc.gov/hai/data/index.html. Accessed 15 February 2021.

5. Suetens C, Latour K, Kärki T, Ricchizzi E, Kinross P, Moro ML, Jans B, Hopkins S, Hansen S, Lyytikainen O, Reilly J, Deptula A, Zingg W, Plachouras D, Monnet DL. Prevalence of healthcare-associated infections, estimated incidence and composite antimicrobial resistance index in acute care hospitals and long-term care facilities: results from two European point prevalence surveys, 2016 to 2017 . Euro Surveill. 2018;23(46). https://doi.org/10.2807/1560-7917.ES.2018.23.46.1800516.

6. World Health Organization. Guidelines on hand hygiene in health care: first global patient safety challenge clean care is safer care. Geneva: WHO. 2009. https://www.ncbi.nlm.nih.gov/books/NBK144030/. Accessed 15 February 2021.

7. Nejad SB, Allegranzi B, Syed SB, Ellis B, Pittet D. Healthcare associated infections in Africa: a systematic review. Bull World Health Organ. 2011;89:759-65. https://www.who.int/bulletin/volumes/89/10/11-088179.pdf.

8. World Health Organization. Report on the burden of endemic health care-associated Infection Worldwide: clean care is safer care. WHO. 2011. https://apps.who.int/iris/bitstream/handle/10665/80135/9789241501507_eng.pdf;jsessionid=B61B01FA0EEB0CD0B3496FDC5E507810? sequence=1. Accessed 15 February 2021.

9. Jamal M, Ahmad W, Andlee S, Jalil F, Imran M, Nawaz MA, Hussain T, Ali M, Rafiq M, Kamil MA. Bacterial biofilm and associated infections. J Chinese Med Assoc. 2018;81:7-11.

10. Vickery K. Special Issue: Microbial biofilms in healthcare: formation, prevention and treatment. materials. 2019. https://doi.org/10.3390/ma12122001.

11. Donlan RM. Role of biofilms in antimicrobial resistance. ASAIO J. 2000;46:47-52.

12. Flemming HC, Wingender J. Relevance of microbial extracellular polymeric substances (EPSs)-Part I: Structural and ecological aspects. Water Sci Technol. 2001;43(6):1-8.

13. Stoodley P, Hall-Stoodley L, Costerton B, DeMeo P, Shirtliff M, Gawalt E, Kathju S. Biofilms, biomaterials, and device-related infections. handbook of polymer applications in medicine and medical devices. 2013. https://doi.org/10.1016/B978-0-323-22805-3.00005-0. 
14. Vickery K, Deva A, Jacombs A, Allan J, Valente P, Gosbell IB. Presence of biofilm containing viable multiresistant organisms despite terminal cleaning on clinical surfaces in an intensive care unit. J Hosp Infect. 2012;80:52-5.

15. Bridier A, Briandet R, Thomas V, Dubois-Brissonnet F. Resistance of bacterial biofilms to disinfectants: a review. Biofouling. 2011;27:101732.

16. Stewart PS. Mechanisms of antibiotic resistance in bacterial biofilms. Int J Med Microbiol. 2002;292:107-13.

17. Otter JA, Vickery K, Walker JT, deLancey Pulcini E, Stoodley P, Goldenberg SD, Salkeld JAG, Chewins J, Yezli S, Edgeworth JD. Surfaceattached cells, biofilms and biocide susceptibility: implications for hospital cleaning and disinfection. J Hosp Infect. 2015;89:16-27.

18. Saggu SK, Jha G, Mishra PC. Enzymatic degradation of biofilm by metalloprotease from microbacterium sp. SKS10. Front Bioeng Biotechnol. 2019;7:192.

19. Chowdhury D, Tahir S, Legge M, Hu H, Prvan T, Johani K, Whiteley GS, Glasbey TO, Deba AK, Vickery K. Transfer of dry surface biofilm in the healthcare environment: the role of healthcare workers' hands as vehicles. J Hosp Infect. 2018;100:e85-90.

20. Almatroudi A, Gosbell IB, Hu H, Jensen SO, Espedido BA, Tahir S, Glasbey TO, Legge P, Whiteley G, Deva A, Vickery K. Staphylococcus aureus dry-surface biofilms are not killed by sodium hypochlorite: implications for infection control. J Hosp Infect. 2016;93:263-70.

21. Ledwoch K, Said J, Norville P, Maillard J-Y. Artificial dry surface biofilm models for testing the efficacy of cleaning and disinfection. Lett Appl Microbiol. 2019;68:329-36.

22. Ledwoch K, Dancer SJ, Otter JA, Kerr K, Roposte D, Rushton L, Weiser RR, Mahenthiralingam E, Muir DD, Maillard J-Y. Beware biofilm! Dry biofilms containing bacterial pathogens on multiple healthcare surfaces; a multi-centre study. J Hosp Infect. 2018;100:e47-56.

23. Mandakhalikar KD, Rahmat JN, Chiong E, Neoh KG, Shen L, Tambyah PA. Extraction and quantification of biofilm bacteria: Method optimized for urinary catheters. Sci Rep. 2018;8:8069.

24. Sievert DM, Ricks P, Edwards JR, Schneider A, Patel J, Srinivasan A, Kallen A, Limbago B, Fridkin S. Antimicrobial-resistant pathogens associated with healthcare-associated infections: summary of data reported to the National Healthcare Safety Network at the Centers for Disease Control and Prevention, 2009-2010. Infect Control Hosp Epidemiol. 2013;34(1):1-4.

25. Weiner LM, Webb AK, Limbago B, Dudeck MA, Patel J, Kallen AJ, Edwards JR, Sievert DM. Antimicrobial-resistant pathogens associated with healthcare-associated infections: summary of data reported to the National Healthcare Safety Network at the Centers for Disease Control and Prevention, 2011-2014. Infect Control Hosp Epidemiol. 2016;37:1288-1301.

26. Almatroudi A, Hu H, Deva A, Gosbell IB, Jacombs A, Jensen SO, Whiteley G, Glasbey T, Vickery K. A new dry-surface biofilm model: An essential tool for efficacy testing of hospital surface decontamination procedures. J Microbiol Methods. 2015;117:171-6.

27. Chang W-S, van de Mortel M, Nielsen L, Nino de Guzman G, Li X, Halverson LJ. Alginate Production by Pseudomonas putida Creates a Hydrated Microenvironment and Contributes to Biofilm Architecture and Stress Tolerance under Water-Limiting Conditions. J Bacteriol. 2007;189:8290-9.

28. Zhang X, Bishop PL. Biodegradability of biofilm extracellular polymeric substances. Chemosphere. 2003;50:63-9.

29. Almatroudi A, Tahir S, Hu H, Chowdhury D, Gosbell IB, Jensen SO, Whiteley GS, Deva AK, Glasbey T, Vickery K. Staphylococcus aureus drysurface biofilms are more resistant to heat treatment than traditional hydrated biofilms. J Hosp Infect. 2018;98:161-7.

30. Flemming HC, Wingender J. The biofilm matrix. Nature Rev Microbiol. 2010;8(9):623-33.

31. Environmental Protection Agency. EPA MLB SOP MB-19: growing a biofilm using the CDC biofilm reactor. EPA. 2017. https://www.epa.gov/sites/production/files/2020-02/documents/mb-19-05.pdf. Accessed 1 August 2019.

32. Mehtar S, Hopman J, Duse A, Doll M. Patient areas and environmental cleaning. Guide to infection control in the hospital. Brookline: Int J Infect Dis. 2018:1-7.

33. Center for Disease Control and Prevention. Disinfection and sterilization. CDC. 2019. https://www.cdc.gov/infectioncontrol/guidelines/disinfection/index.html. Accessed 15 February 2021.

34. Nkemngong CA, Voorn MG, Li X, Teska PJ, Oliver HF. A rapid model for developing dry surface biofilms of Staphylococcus aureus and Pseudomonas aeruginosa for in vitro disinfectant efficacy testing. Antimicrob Resist Infect Control. 2020;9:134.

35. Environmental Protection Agency. Methods and guidance for testing the efficacy of antimicrobial products against biofilms on hard, nonporous surfaces. EPA. 2017. https://www.epa.gov/pesticide-analytical-methods/methods-and-guidance-testing-efficacy-antimicrobialproducts-against\#efficacy-data. Accessed 31 July 2019.

36. Lineback CB, Nkemngong CA, Wu ST, Li X, Teska PJ, Oliver HF. Hydrogen peroxide and sodium hypochlorite disinfectants are more effective against Staphylococcus aureus and Pseudomonas aeruginosa biofilms than quaternary ammonium compounds. Antimicrob Resist Infect Control. 2018;7:154.

37. Amaeze N, Akinbobola A, Chukwuemeka V, Abalkhaila A, Ramage G, Kean R, Staines H, Williams C, Mackay W. Development of a high throughput and low cost model for the study of semi-dry biofilms. Biofouling. 2020;36:403-15.

38. Denyer SP, Stewart GSAB. Mechanisms of action of disinfectants. Int Biodeterior Biodegrad. 1998;41:261-8.

Page $9 / 12$ 
39. Finnegan M, Linley E, Denyer SP, McDonnell G, Simons C, Maillard JY. Mode of action of hydrogen peroxide and other oxidizing agents: differences between liquid and gas forms. J Antimicrob Chemother. 2010;65(10):2108-15.

40. Jennings LK, Storek KM, Ledvina HE, Coulon C, Marmont LS, Sadovskaya I, Secor PR, Tseng BS, Scian M, Filloux A, Wozniak DJ, Howell PL, Parsek MR. Pel is a cationic exopolysaccharide that cross-links extracellular DNA in the Pseudomonas aeruginosa biofilm matrix. Proc Natl Acad Sci. 2015;112:11353-8.

41. Fleming J. The Benefits of Alcohol-Quaternary Ammonium Germicidal Wipes. 2009. https://www.infectioncontroltoday.com/view/benefitsalcohol-quaternary-ammonium-germicidal-wipes. Accessed 15 February 2021.

42. Voorn MG, Goss SE, Nkemngong CA, Li X, Teska PJ, Oliver HF. Cross-contamination by disinfectant towelettes varies by product chemistry and strain. Antimicrob Resist Infect Control. 2020;9:141.

43. West AM, Nkemngong CA, Voorn MG, Wu T, Li X, Teska PJ, Oliver HF. 2018. Surface area wiped, product type, and target strain impact bactericidal efficacy of ready-to-use disinfectant towelettes. Antimicrob Resist Infect Control. 2018 Oct 11;7:122.

44. Toté K, Horemans T, Berghe DV, Maes L, Cos P. Inhibitory effect of biocides on the viable masses and matrices of Staphylococcus aureus and Pseudomonas aeruginosa biofilms. Appl Environ Microbiol. 2010;76:3135-42.

45. Tiwari S, Rajak S, Mondal DP, Biswas D. Sodium hypochlorite is more effective than $70 \%$ ethanol against biofilms of clinical isolates of Staphylococcus aureus. Am J Infect Control. 2018;46(6):e37-e42.

46. Wesgate R, Robertson A, Barrell M, Teska P, Maillard J-Y. Impact of test protocols and material binding on the efficacy of antimicrobial wipes. J Hosp Infect. 2019;103:e25-32.

47. Abdallah M, Khelissa O, Ibrahim A, Benoliel C, Heliot L, Dhulster P, Chihib N-E. Impact of growth temperature and surface type on the resistance of Pseudomonas aeruginosa and Staphylococcus aureus biofilms to disinfectants. Int J Food Microbiol. 2015;214:38-47.

48. Ghafoor A, Hay ID, Rehm BHA. Role of exopolysaccharides in Pseudomonas aeruginosa biofilm formation and architecture. Appl Environ Microbiol. 2011;77:5238-46.

49. Allesen-Holm M, Barken KB, Yang L, Klausen M, Webb JS, Kjelleberg S, Molin S, Givskov M, Nielsen TT. A characterization of DNA release in Pseudomonas aeruginosa cultures and biofilms. Mol Microbiol. 2006;59:1114-28.

50. Hay ID, Remminghorst U, Rehm BH. MucR, a novel membrane-associated regulator of alginate biosynthesis in Pseudomonas aeruginosa. AEM. 2009;75(4):1110-20.

51. Pier GB, Coleman F, Grout M, Franklin M, Ohman DE. Role of alginate $\mathrm{O}$ acetylation in resistance of mucoid Pseudomonas aeruginosa to opsonic phagocytosis. Infect Immun. 2001;69(3):1895-901.

52. Colvin KM, Gordon VD, Murakami K, Borlee BR, Wozniak DJ, Wong GC, Parsek MR. The pel polysaccharide can serve a structural and protective role in the biofilm matrix of Pseudomonas aeruginosa. PLoS Pathog. 2011 Jan 27;7(1):e1001264.

53. Mcdonnell G, Russell AD. Antiseptics and Disinfectants: Activity, Action, and Resistance. Clin Microbiol Rev. 1999;12:34.

54. Bloomfield S F. Chlorine and iodine formulations. In: Ascenzi J M, editor. Handbook of disinfectants and antiseptics. New York, N.Y: Marcel Dekker, Inc.; 1996. pp. 133-158.

55. Block S S. Peroxygen compounds. In: Block S S, editor. Disinfection, sterilization, and preservation. 4th ed. Philadelphia, Pa: Lea \& Febiger; 1991. pp. 167-181.

\section{Figures}




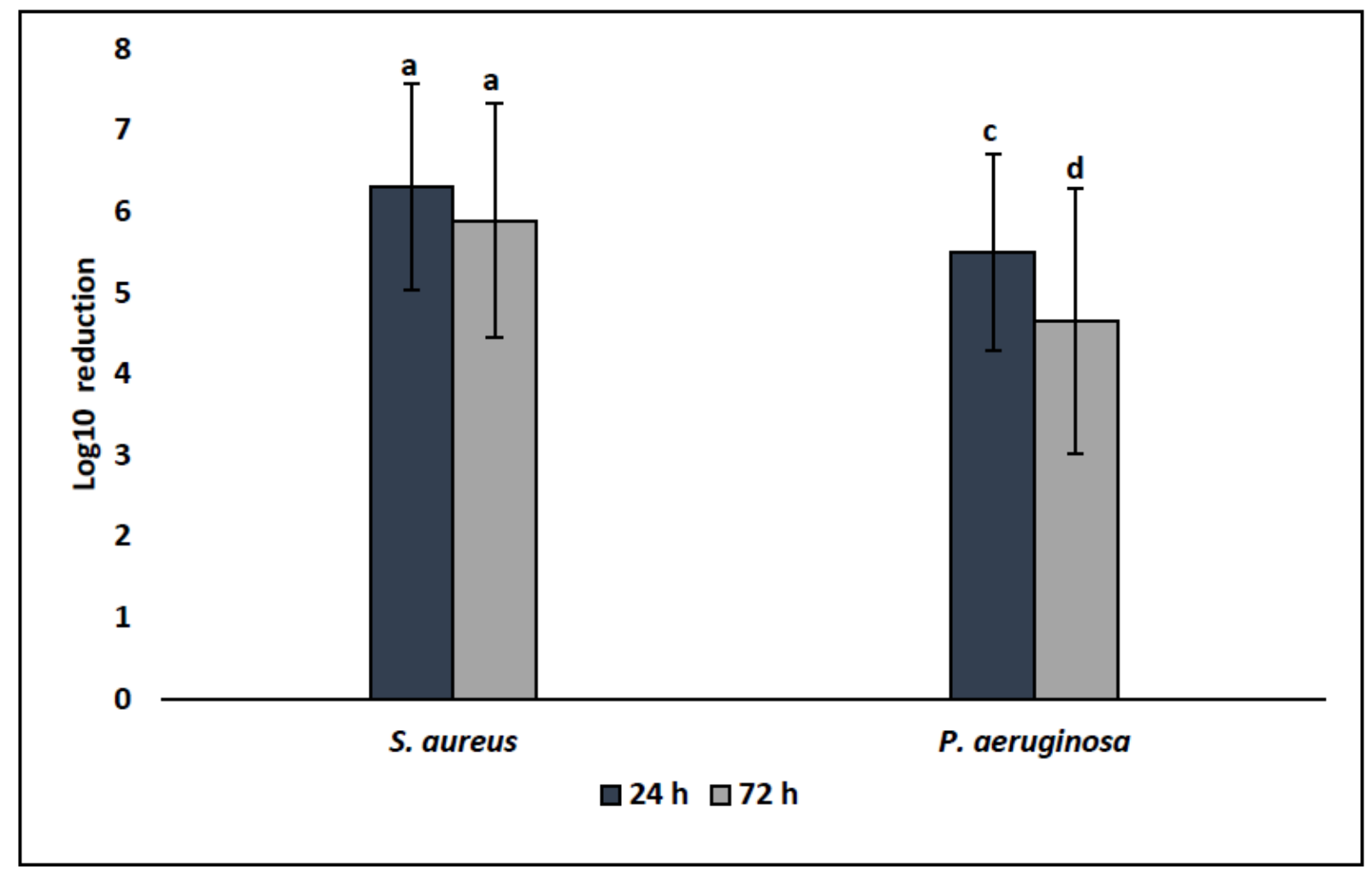

Figure 1

Disinfectant efficacy against DSB of S. aureus and P. aeruginosa by dry time. Letter (a) Tukey grouping for disinfectant efficacy against S. aureus DSB only. Letters are (c, d) Tukey grouping for disinfectant efficacy against DSB of P. aeruginosa only.

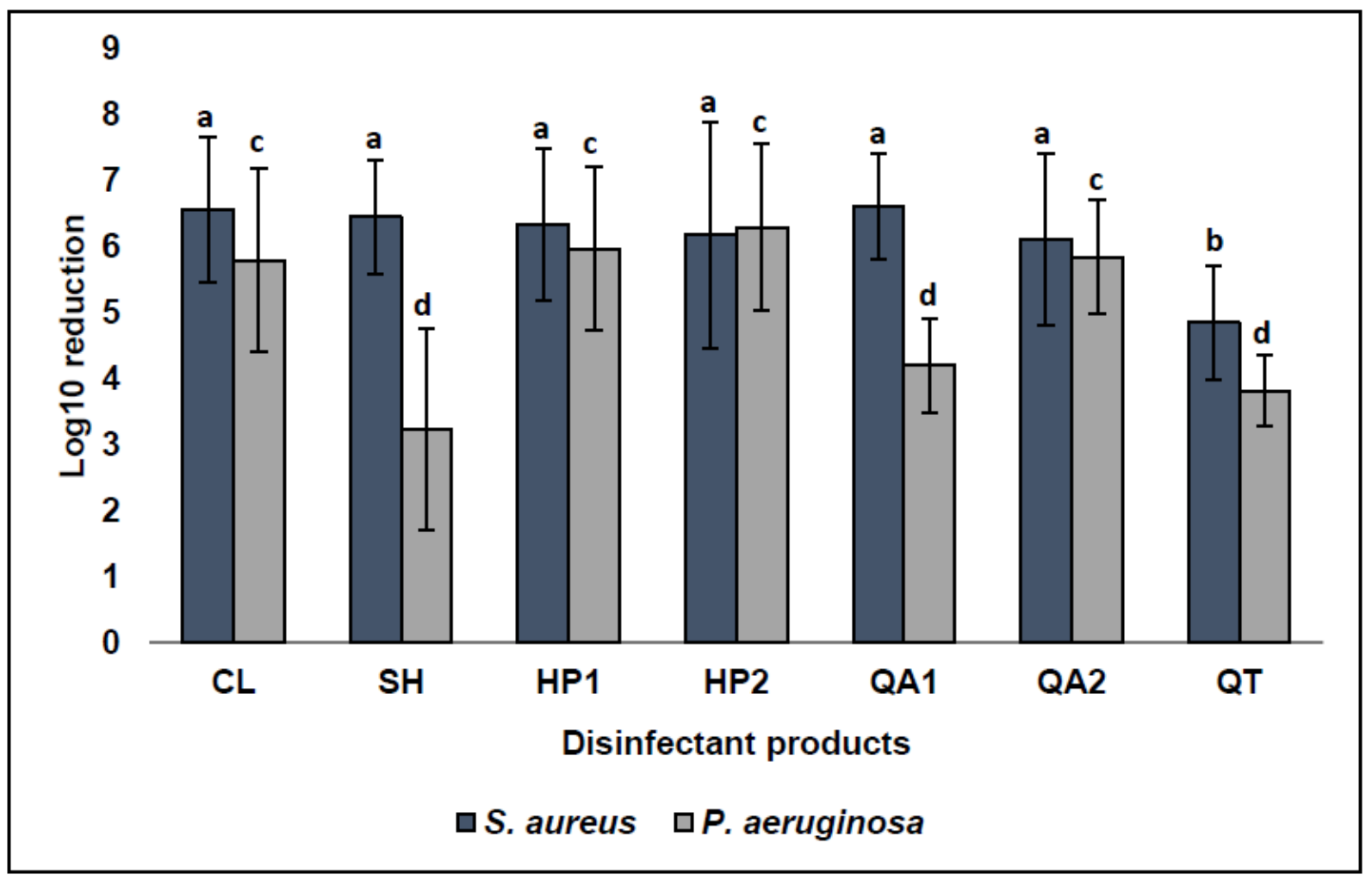

Figure 2

Disinfectant efficacy against DSB of S. aureus and P. aeruginosa by product type. Letters $(a, b)$ Tukey grouping for disinfectant efficacy against S. aureus DSB only. Letters are (c, d) Tukey grouping for disinfectant efficacy against DSB of P. aeruginosa only. 


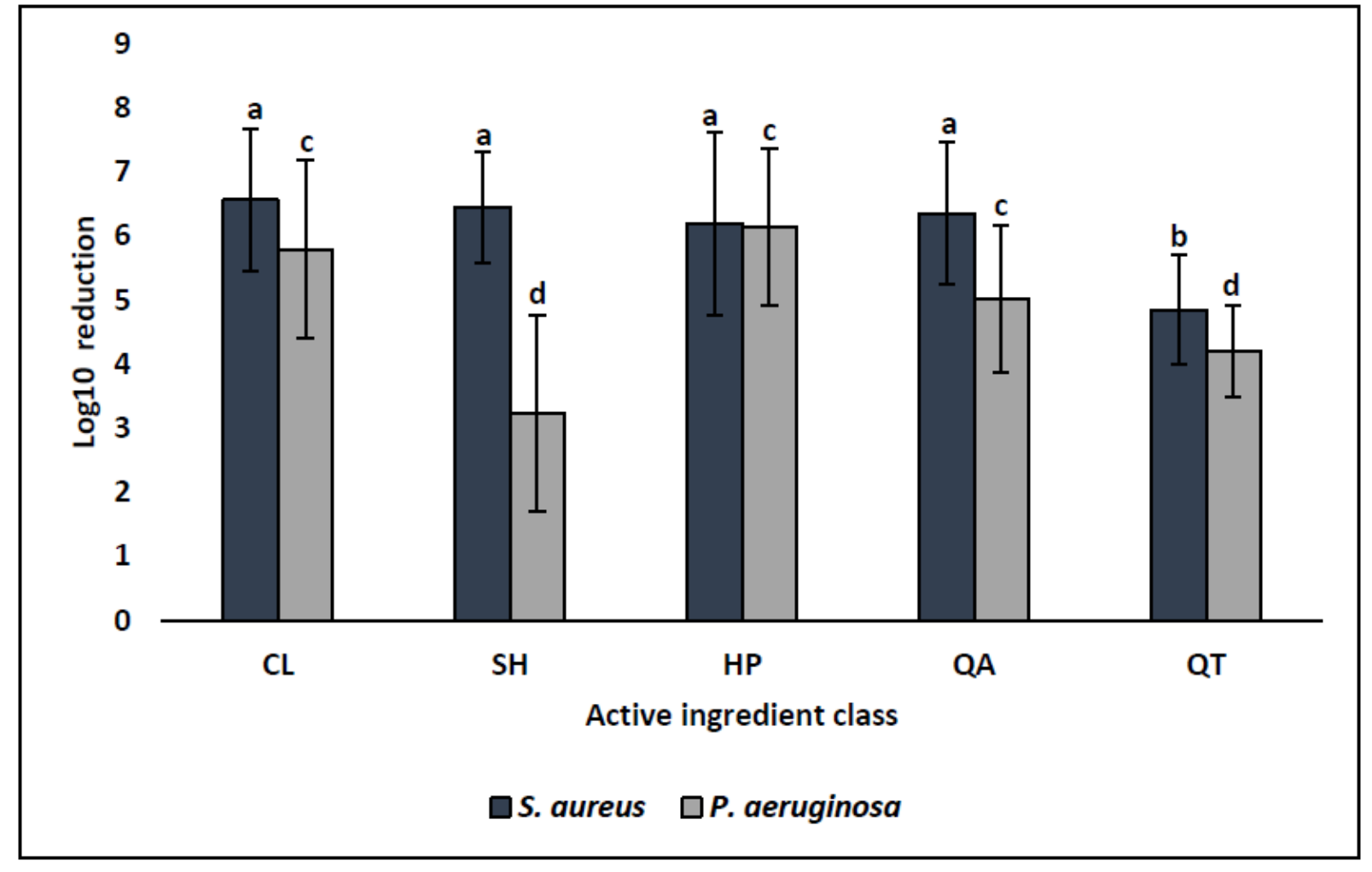

Figure 3

Disinfectant efficacy against DSB of S. aureus and P. aeruginosa by active ingredient class. Letters are (a, b) Tukey grouping for disinfectant efficacy against S. aureus DSB only. Letters are (c, d) Tukey grouping for disinfectant efficacy against DSB of P. aeruginosa only. 